\title{
Association between life-style behaviors and health outcomes in Adventist and non- Adventist adolescents in Mexico: a pilot study
}

Maria Elena Acosta Enríquez ${ }^{1}$, Felipe Javier Uribe Salas², Juha Baek ${ }^{3}$, Jenny Patricia Sierra Archbold ${ }^{1}$ and Genny Carrillo ${ }^{3^{*}}$ (D)

\begin{abstract}
Background: Identifying lifestyle-related health predictors affecting adolescent behaviors is a matter of interest and study for diverse audiences, including the religious sphere. The Adventist religion recommends their followers to adopt a healthy diet, adequate rest, physical activity, sufficient water intake, and non-use of addictive substances such as alcohol, tobacco, and drugs, as well as fostering faith and hope to give meaning to life.

Methods: A cross-sectional and observational study was conducted among adolescent students aged 13 to 19 years old in Montemorelos City, Nuevo León, Northern Mexico, between September 14, 2017 and February 13, 2018. This study included 363 Mexican adolescents, consisting of 202 Adventists and 161 non-Adventists. The binomial logistic regression analysis was performed to examine the relationships between religious affiliation and life-style behaviors and evaluate the effect of life-style behaviors on health outcomes by religious affiliation. Age, gender, type of residence, and place of birth were controlled.
\end{abstract}

Results: We found that Adventist adolescents were more likely to be watching TV for $2 \mathrm{~h}$ or less per day $(p<0.001)$, have enough sleeping time for $7 \mathrm{~h}$ or more $(p<0.001)$, go to bed early at 11 o'clock or before $(p<0.001)$, and have breakfast $(p=0.006)$ than non-Adventist adolescents significantly. It indicates that Adventist students are more likely to have healthier life-style behaviors than non-Adventist students. The multiple binomial regression models showed that in the group of Adventist adolescents sporting activity and hours watching TV were significantly associated with obesity risk $(p=0.001)$ and risky eating patterns $(p=0.044)$, respectively, controlling for age, gender, type of residence, and place of birth. No relationship was found between life-style behaviors and health outcomes in nonAdventist adolescents.

Conclusions: Religious affiliation could serve as a predictor of healthy behaviors among adolescents. This study concluded that Adventist adolescents are more likely to have a healthier lifestyle behavior than non-Adventist adolescents and various health-related behaviors were specifically identified among Adventist participants.

Keywords: Adolescents, Life-style behaviors, Health outcomes, Adventist religious affiliation, Mexico

\footnotetext{
* Correspondence: gcarrillo@tamu.edu

${ }^{3}$ Department of Environmental and Occupational Health, School of Public

Health, Texas A\&M University, 212 Adriance Lab Road, Suite 110, College

Station, TX, USA

Full list of author information is available at the end of the article
}

(c) The Author(s). 2019 Open Access This article is distributed under the terms of the Creative Commons Attribution 4.0 International License (http://creativecommons.org/licenses/by/4.0/), which permits unrestricted use, distribution, and reproduction in any medium, provided you give appropriate credit to the original author(s) and the source, provide a link to the Creative Commons license, and indicate if changes were made. The Creative Commons Public Domain Dedication waiver (http://creativecommons.org/publicdomain/zero/1.0/) applies to the data made available in this article, unless otherwise stated. 


\section{Background}

The family, social environment, habits, lifestyle, nutrition and health status, and self-perception of body image perception among adolescents demonstrate reasons to identify and understand these behaviors that affect their development, growth, morbidity, and quality of life [1-5]. Various organizations and even religious groups have been interested in adopting health principles that help the reduction of non-communicable diseases. These principles have been observed over time and described in scientific literature, such as those made by the Seventh-day Adventist Church (SDA) since the mid-nineteenth century [6-9]. They have also promoted healthy behaviors such as a vegetarian diet, no alcohol intake, and non-use of tobacco or other addictive substances. In addition, these principles include an appropriate rest, increased recreational physical activity, and development of their faith and hope. Garcia et al. [10] found that Adventist religion principles could influence positively in individual's physical health, while Miller et al. [11] and Saunders et al. [12] reported a positive effect on mental health.

Previous studies conducted in the Adventist population have examined the impact of lifestyle habits on the prevalence of morbidity and mortality of diseases such as obesity, diabetes, dyslipidemia, heart disease, and cancer $[6,7$, 13-16]. During the last 20 years, some researchers have studied the association between religiosity and spirituality in health maintenance and recovery from cross-sectional and longitudinal studies [7, 11, 12, 14-17]. On the other hand, there are few peer-reviewed articles on the relationship between the Adventist religion and the adoption of healthy behaviors in Mexican adolescents. Some unpublished reports evaluated nutritional status, eating habits, body composition, and application of promotional health interventions in children and adolescents [18]. However, other studies have found that healthy lifestyle behaviors are associated with religion and planned activities in Australian [7, 8], Asian [9, 14], Latino [10], American and Czech $[19,20]$ adolescents.

It has been observed that adolescents and young people involved in some religious affiliation exhibit healthier behaviors, such as participating more actively in extracurricular activities during their free time [21-26] and getting more involved in family and religious social interaction [27, 28 ] than those who do not. Researchers found that religious affiliation could represent a protective model to reduce obesity and other diseases associated with lifestyle [19], and risks from a history of morbidity [29]. Interventions promoting adolescents' health should teach them to take care of themselves [30], provide support for parents and their teachers [25, 27], and learn about their social environment and background, in order to be more impactful [13]. The purpose of this study was to compare life-style behaviors between Adventist and non-Adventist adolescents in
Mexico and examine the associations between life-style behaviors and health outcomes by religious affiliation.

\section{Methods \\ Participants and settings}

A cross-sectional and observational study was conducted among adolescent students aged 13 to 19 years old in Montemorelos City, Nuevo León, Northern Mexico, between September 14, 2017 and February 13, 2018. The study participants were recruited from two middle schools and two high schools, which included one private and one public school, respectively. The population was selected for convenience due to the availability of the subjects to participate in the study. It represents a population cohort that has been evaluated by anthropometry since school age. This study only reports the evaluation data of the last wave of information corresponding to the period of 2017-2018, with a verbal assent from all of adolescent participants and a written consent form from their parents. The study was approved by the Ethics Committee of the Department of Health Teaching and the Health and Research Ministry of in the state of Nuevo León, Registration 194,805,068 and the Regional Office of Education.

\section{Measurements}

The socio-demographic, lifestyle behaviors and health outcomes information were gathered from a non-validated survey questionnaire developed by our research team from direct measurements for height and weight (See Supplementary file). The socio-demographic information included age (years), gender (female or male), place of birth (north Mexico or others), nationality (Mexican or others), school level (middle or high school), type of residence (living with family or living in boarding school), and personal religion (Adventist or non-Adventist). With regards with lifestyle behaviors information, the survey asked participants the following questions: watching TV per a day (hours), sleeping times (hours), time to sleep (o'clock), time to wake up (o'clock), sporting activity (yes or no), and having breakfast (yes or no).

The health outcomes included obesity risk, eating risk scale, and body image self-perception scales. First, the obesity risk was evaluated by using the body mass index (BMI) calculator for child and teen of the Centers for Disease Control and Prevention (CDC) [31]. That is, BMI for each adolescent was calculated as a percentile obtained from a BMI percentile calculator considering age and gender [31, 32]. As a result, the obesity status had four categories as follows: 1) underweight (below the 5th percentile), 2) normal or healthy weight (the 5th to less than the 85th percentiles), 3) overweight (the 85th to less than 95th percentiles), and 4) obesity (the 95th percentile or above) [31]. In the regression models, 
a binary variable (obese/overweight or normal/underweight) was used to examine a risk of obesity including obese and overweight status.

Second, the eating behavior risk scales of participants were evaluated by using the method of Unikel et al. [33], consisting of a Lickert-style questionnaire with 10 items about the frequency of behaviors during one week (See Supplementary file). Each question took the following values: 0 (never or almost never), 1 (sometimes), 2 (frequently, twice a week), and 3 (very often, more than twice a week). The total score of the scale (0 to 30) was obtained by adding all values of ten questions, indicating the degree of risk in the eating behavior [33]. The following cut-off points were used to evaluate the continuum of the scale: 1) no risk (0 to 6 points), 2) moderate risk (7 to 10 points and 3 ) high risk (11 or higher points), according to Altamirano et al. [34]. Considering the percentages of each group, we used a binary variable (risk free: 0 to 6 points or having a risk: 7 or higher) in this study.

Lastly, the research team followed the methodology proposed by Gardner et al. and Rueda-Jaimes et al. [35, 36] to evaluate the self-perception about body image among participants. This scale (Standard Figural Stimuli, SFS) consists of 9 silhouettes representing the human figure. The central silhouette indicates the median of weight distribution in the reference population and six silhouettes on left and right sides of the center show progressive increase or decrease in weight. In the questionnaire, participants were asked to select the silhouette that they perceive as their current weight, and the silhouette as their ideal weight. With these measurements two indexes were obtained: a) dissatisfaction index of the body image by calculating the difference between the current perceived image and the desired (or ideal) image, and b) distortion index of the body image by calculating the difference between the perceived image and the real one (real BMI category). In this study, we used satisfaction (satisfaction or dissatisfaction) and distortion (distortion or no distortion) variables as body image self-perception scales.

\section{Statistical analysis}

We calculated descriptive statistics of the study population to estimate mean, standard deviation (SD), minimum (Min) and maximum (Max) values for continuous variables or percentages for categorical variables. The MannWhitney $U$ tests for continuous variables such as age, BMI, eating risk scale, hours watching TV, and sleeping time, and the Chi-square tests for categorical variables, including age, gender, place of birth, nationality, school level, type of residence, obesity risk, eating risk scale, dissatisfaction, distortion, hours watching TV, sleeping time per day, time when going to sleep, time to wake up, sporting activity, and having breakfast, were conducted to determine whether socio-demographic characteristics, life- style behaviors, and health outcomes were significantly different between Adventist and non-Adventist adolescent groups.

In addition, the binomial logistic regression analysis was used to figure out the associations between religious affiliation (Adventist or not) and life-style behaviors controlling for age, sex, type of residence, and place of birth. To examine life-style behaviors factors associated with health outcomes by religious affiliation, we used two types of the binomial logistic regression models. The first models controlled for only other life-style behaviors factors and the second models adjusted for other life-style behaviors and some socio-demographic factors, including age, gender, type of residence, and place of birth. The odds ratios (ORs) with 95\% confidence intervals (CIs) showed the relationships between individual behavioral factors and each health outcome while controlling for other factors. The "school grade" variable was excluded in the regression models because of its collinearity effect with "age" variable. A $p$-value $<0.05$ was considered significant. All analyses were conducted by using Stata version 14 (StataCorp LP, College Station, TX).

\section{Results}

A total of 363 students participated in this study and Adventist and non-Adventist adolescents included 202 (55.6\%) and 161 (44.4\%), respectively. Descriptive statistics of the study participants about socio-demographic and health-related characteristics are presented in Table 1 . The mean age of all participants was 15 years old and Adventist were averagely a little older than non-Adventist students $(15.3$ vs. 14.7 years, $p<0.001)$. Less than half of participants $(44.4 \%)$ were under 15 years (13-15 years). Percentages of female and male students were similar but Adventists (51.5\%) had more male students than nonAdventists (47.8\%). About $62 \%$ of students were born in North Mexico and most of participants (92.3\%) had Mexican nationality. In addition, over $90 \%$ of students were living with family but more Adventists (15.4\%) were living in boarding school than non-Adventists $(1.9 \%)(p<0.001)$.

In terms of health-related factors, the average BMI of all participants was $22.4\left(\mathrm{~kg} / \mathrm{m}^{2}\right)$ and there was no big difference between Adventists and non-Adventists. The joint prevalence of overweight and obesity was $27.8 \%$ and Adventists (24.1\%) had lower prevalence than non-Adventists (32.7\%). Moreover, the prevalences of risky eating patterns, self-perception body image dissatisfaction and body image distortion were 19.6, 59 and $28.6 \%$, respectively. When comparing Adventists with non-Adventists, Adventist students had more risk eating patterns (22.3\% vs. $16.2 \%)$, higher satisfaction $(43.1 \%$ vs. $37.9 \%)$, and lower no distortion ( $28 \%$ vs. $29.4 \%)$. However, none of the health outcomes showed significant differences between Adventist and non-Adventist adolescents. 
Table 1 Descriptive statistics of study participants in Montemorelos, Nuevo León, Mexico ( $N=363)$

\begin{tabular}{|c|c|c|c|c|}
\hline \multirow[t]{2}{*}{ Variable } & Total $(N=363)$ & Adventist $(N=202)$ & Non-Adventist $(N=161)$ & p-value \\
\hline & \multicolumn{4}{|c|}{ Mean \pm S.D. [Min, Max] or \% } \\
\hline Age (years) & $15.0 \pm 1.2[13,19]$ & $15.3 \pm 1.1[14,19]$ & $14.7 \pm 1.3[13,19]$ & $<0.001$ \\
\hline \multicolumn{4}{|l|}{ Age } & $<0.001$ \\
\hline Less than 15 years old & $44.4 \%$ & $29.2 \%$ & $63.3 \%$ & \\
\hline 15 years old or older & $55.6 \%$ & $70.8 \%$ & $36.7 \%$ & \\
\hline \multicolumn{4}{|l|}{ Gender } & 0.489 \\
\hline Female & $50.1 \%$ & $48.5 \%$ & $52.2 \%$ & \\
\hline Male & $49.9 \%$ & $51.5 \%$ & $47.8 \%$ & \\
\hline \multicolumn{4}{|l|}{ Place of birth } & $<0.001$ \\
\hline North Mexico & $62.3 \%$ & $41.6 \%$ & $88.2 \%$ & \\
\hline Other $^{a}$ & $37.7 \%$ & $58.4 \%$ & $11.8 \%$ & \\
\hline \multicolumn{4}{|l|}{ Nationality } & 0.034 \\
\hline Mexican & $92.3 \%$ & $91.4 \%$ & $96.9 \%$ & \\
\hline Other ${ }^{\mathrm{b}}$ & $6.2 \%$ & $8.6 \%$ & $3.1 \%$ & \\
\hline \multicolumn{4}{|l|}{ School level } & $<0.001$ \\
\hline Middle school & $45.2 \%$ & $29.2 \%$ & $65.2 \%$ & \\
\hline High school & $54.8 \%$ & $70.8 \%$ & $34.8 \%$ & \\
\hline \multicolumn{4}{|l|}{ Type of residence } & $<0.001$ \\
\hline Living with family & $90.6 \%$ & $84.6 \%$ & $98.1 \%$ & \\
\hline Living in boarding school & $9.4 \%$ & $15.4 \%$ & $1.9 \%$ & \\
\hline $\mathrm{BMI}\left(\mathrm{kg} / \mathrm{m}^{2}\right)$ & $22.4 \pm 4.0[14.6,36.9]$ & $22.3 \pm 3.7[14.7,35.5]$ & $22.7 \pm 4.5[14.6,36.9]$ & 0.745 \\
\hline \multicolumn{4}{|l|}{ Obesity risk } & 0.076 \\
\hline Underweight/normal & $72.2 \%$ & $75.9 \%$ & $67.3 \%$ & \\
\hline Overweight/obesity & $27.8 \%$ & $24.1 \%$ & $32.7 \%$ & \\
\hline Eating risk scale (continuous) & $4.3 \pm 3.7[0,22]$ & $4.6 \pm 3.8[0,22]$ & $3.9 \pm 3.5[0.20]$ & 0.06 \\
\hline \multicolumn{4}{|l|}{ Eating risk scale } & 0.144 \\
\hline Risk free (0-6) & $80.4 \%$ & $77.7 \%$ & $83.8 \%$ & \\
\hline Risk (7 or above) & $19.6 \%$ & $22.3 \%$ & $16.2 \%$ & \\
\hline \multicolumn{4}{|l|}{ Dissatisfaction } & 0.318 \\
\hline Dissatisfaction & $40.8 \%$ & $56.9 \%$ & $62.1 \%$ & \\
\hline Satisfaction & $59.0 \%$ & $43.1 \%$ & $37.9 \%$ & 0.771 \\
\hline \multicolumn{5}{|l|}{ Distortion } \\
\hline Distortion & $71.4 \%$ & $72.0 \%$ & $70.6 \%$ & \\
\hline No distortion & $28.6 \%$ & $28.0 \%$ & $29.4 \%$ & \\
\hline
\end{tabular}

Note: ${ }^{\mathrm{a} C e n t r a l}$ Mexico, South and Southeastern Mexico, and other country; ${ }^{\mathrm{b} U S A}$, Central American, South American, and European

Table 2 shows compares life-style behaviors characteristics between Adventist and non-Adventist adolescents. The mean hours watching TV per day was $2.7 \mathrm{~h}$ and Adventists $(2.2 \mathrm{~h})$ watched TV less than non-Adventists (3.4h) daily $(p<0.001)$. Percentages of adolescents who watched TV more than $2 \mathrm{~h}$ per day were much less in Adventists $(22.8 \%)$ than non-Adventists $(79.5 \%)(p<0.001)$. Participants slept for $6.8 \mathrm{~h}$ per day averagely and Adventists $(7.1 \mathrm{~h}) \mathrm{had}$ longer sleeping time than non-Adventists $(6.4 \mathrm{~h})$ on average $(p<0.001)$. There was a large difference in percentages of students who slept for $7 \mathrm{~h}$ or more between Adventists and non-Adventists (80.7\% vs. $48.5 \%)$ $(p<0.001)$. In addition, percentages of Adventists who went to sleep early (11 PM or before) and woke up late (after $6 \mathrm{PM})$ were higher than non-Adventists $(80.2 \%$ vs. $54 \%, p<0.001 ; 80.2 \%$ vs. $88.2 \%, p=0.04)$. The rate of students who attended any sporting activity was higher in non-Adventists than Adventists but the difference was not significant. Lastly, about $71 \%$ of adolescents had breakfast and the percentage of those having breakfast 
Table 2 Comparisons of life-style behaviors between Adventist and Non-Adventist adolescents

\begin{tabular}{|c|c|c|c|c|}
\hline \multirow[t]{2}{*}{ Variable } & Total $(\mathrm{N}=363)$ & Adventist $(N=202)$ & Non-Adventist $(N=161)$ & $p$-value \\
\hline & \multicolumn{4}{|c|}{ Mean \pm SD [Min, Max] or \% } \\
\hline Hours watching TV (hours) & $2.7 \pm 1.5[1,7]$ & $2.2 \pm 1.5[1,7]$ & $3.4 \pm 1.2[1,7]$ & $<0.001$ \\
\hline \multicolumn{4}{|l|}{ Hours watching TV per day } & $<0.001$ \\
\hline Two hours or less & $52.1 \%$ & $77.2 \%$ & $20.5 \%$ & \\
\hline More than two hours & $47.9 \%$ & $22.8 \%$ & $79.5 \%$ & \\
\hline Sleeping time (hours) & $6.8 \pm 1.1[4,10]$ & $7.1 \pm 1.0[4.3,10]$ & $6.4 \pm 1.0[4,9]$ & $<0.001$ \\
\hline \multicolumn{4}{|l|}{ Sleeping time per day } & $<0.001$ \\
\hline Seven hours or more & $66.4 \%$ & $80.7 \%$ & $48.5 \%$ & \\
\hline Less than seven hours & $33.6 \%$ & $19.3 \%$ & $51.5 \%$ & \\
\hline \multicolumn{4}{|l|}{ Time when going to sleep } & $<0.001$ \\
\hline $11 \mathrm{PM}$ or before $11 \mathrm{PM}$ & $68.6 \%$ & $80.2 \%$ & $54.0 \%$ & \\
\hline After 11 PM & $31.4 \%$ & $19.8 \%$ & $46.0 \%$ & \\
\hline \multicolumn{4}{|l|}{ Time to wake up } & 0.040 \\
\hline $6 \mathrm{AM}$ or before $6 \mathrm{AM}$ & $83.7 \%$ & $80.2 \%$ & $88.2 \%$ & \\
\hline After 6 PM & $16.3 \%$ & $19.8 \%$ & $11.8 \%$ & \\
\hline \multicolumn{4}{|l|}{ Sporting activity ${ }^{a}$} & 0.698 \\
\hline Yes & $60.7 \%$ & $59.8 \%$ & $61.8 \%$ & \\
\hline No & $39.3 \%$ & $40.2 \%$ & $38.2 \%$ & \\
\hline \multicolumn{4}{|l|}{ Having breakfast } & $<0.001$ \\
\hline Yes & $70.8 \%$ & $78.7 \%$ & $60.9 \%$ & \\
\hline No & $29.2 \%$ & $21.3 \%$ & $39.1 \%$ & \\
\hline
\end{tabular}

Note: ${ }^{a}$ Sporting activity includes football, basketball, and volleyball

was higher in Adventists (78.7\%) than non-Adventists $(60.9 \%)(p<0.001)$.

To examine associations between religious affiliation and life-style behaviors, we conducted multiple binomial logistic regression analysis. The results of the regression models adjusting for age, sex, type of residence, and place of birth are shown in Table 3. We found that Adventist adolescents were more likely to be watching TV for $2 \mathrm{~h}$ or less per day $(p<0.001)$, have enough sleeping time for $7 \mathrm{~h}$ or more $(p<0.001)$, go to bed early at 11 o'clock or before $(p<0.001)$, and have breakfast $(p=0.006)$ than non-Adventist adolescents significantly. It indicates that Adventist students are more likely to have healthier life-style behaviors than non-Adventist students. The time to wake up and sporting activity did not show significant results.

Table 4 demonstrates the results of associations between life-style behaviors and health outcomes by religious affiliation. The results of binomial logistics regression models showed that sporting activity was significantly associated with obesity risk in the group of Adventist adolescents. That is, students who attended any sporting activity were less likely to have obesity risk (overweight or obesity status) than those who did not attend any sporting activity. The significant results were found in both the model $1(p=$ $0.019)$ and model $2(p=0.001)$. In addition, we found that hours watching TV had a significant relationship

Table 3 Associations between religious affiliation and life-style behaviors

\begin{tabular}{|c|c|c|c|c|c|c|}
\hline & \multicolumn{6}{|c|}{ Adjusted OR (95\% Cl) } \\
\hline & $\begin{array}{l}\text { Watching TV } \\
\text { ( } 2 \mathrm{~h} \text { or less) }\end{array}$ & $\begin{array}{l}\text { Sleeping time } \\
\text { (7 h or more) }\end{array}$ & $\begin{array}{l}\text { Time to sleep } \\
\text { (11 o'clock or before) }\end{array}$ & $\begin{array}{l}\text { Time to wake up } \\
\text { (6 o'clock or before) }\end{array}$ & $\begin{array}{l}\text { Sporting activity } \\
\text { (Yes) }\end{array}$ & $\begin{array}{l}\text { Having breakfast } \\
\text { (Yes) }\end{array}$ \\
\hline \multicolumn{7}{|l|}{ Religion } \\
\hline Non-Adventist & 1 (Ref.) & 1 (Ref.) & 1 (Ref.) & 1 (Ref.) & 1 (Ref.) & 1 (Ref.) \\
\hline Adventist & $\begin{array}{l}14.3 \\
(7.86-25.87)^{* * *}\end{array}$ & $\begin{array}{l}4.37 \\
(2.53-7.57)^{* * *}\end{array}$ & $3.8(2.19-6.70)^{* * *}$ & $\begin{array}{l}0.83 \\
(0.41-1.68)\end{array}$ & $\begin{array}{l}1.28 \\
(0.71-2.30)\end{array}$ & $2.11(1.23-3.60)^{* *}$ \\
\hline
\end{tabular}

Note: OR Odds Ratio, $95 \% \mathrm{Cl}=95 \%$ Confidence Interval, adjusted for age, sex, type of residence, and place of birth ${ }^{*} p<0.05,{ }^{* *} p<0.01,{ }^{* * *} p<0.001$ 
Table 4 Associations between life-style behaviors and health outcomes by religious affiliation

\begin{tabular}{|c|c|c|c|c|c|c|c|c|}
\hline \multirow[t]{3}{*}{ Life-style behaviors } & \multicolumn{2}{|l|}{ Obesity risk } & \multirow{2}{*}{\multicolumn{2}{|c|}{$\frac{\text { Risky eating patterns }}{\text { Adjusted OR }(95 \% \mathrm{Cl})}$}} & \multirow{2}{*}{\multicolumn{2}{|c|}{$\begin{array}{l}\text { Dissatisfaction } \\
\text { Adjusted OR (95\% Cl) }\end{array}$}} & \multirow{2}{*}{\multicolumn{2}{|c|}{$\begin{array}{l}\text { Distortion } \\
\text { Adjusted OR (95\% Cl) }\end{array}$}} \\
\hline & \multicolumn{2}{|c|}{ Adjusted OR (95\% Cl) } & & & & & & \\
\hline & Model $1^{\mathrm{a}}$ & Model $2^{\mathrm{b}}$ & Model $1^{\mathrm{a}}$ & Model $2^{b}$ & Model $1^{\mathrm{a}}$ & Model $2^{\mathrm{b}}$ & Model $1^{\mathrm{a}}$ & Model $2^{b}$ \\
\hline \multicolumn{9}{|l|}{ Adventist adolescents } \\
\hline \multicolumn{9}{|l|}{ Hours watching TV } \\
\hline More than $2 \mathrm{~h}$ & 1 (ref.) & 1 (ref.) & 1 (ref.) & 1 (ref.) & 1 (ref.) & 1 (ref.) & 1 (ref.) & 1 (ref.) \\
\hline $2 \mathrm{~h}$ or less & $\begin{array}{l}2.13 \\
(0.82-5.49)\end{array}$ & $\begin{array}{l}1.51 \\
(0.55-4.10)\end{array}$ & $\begin{array}{l}0.45^{*} \\
(0.21-0.98)\end{array}$ & $\begin{array}{l}0.44^{*} \\
(0.20-0.98)\end{array}$ & $\begin{array}{l}1.05 \\
(0.52-2.09)\end{array}$ & $\begin{array}{l}1.11 \\
(0.55-2.25)\end{array}$ & $\begin{array}{l}1.52 \\
(0.73-3.16)\end{array}$ & $\begin{array}{l}1.56 \\
(0.73-3.32)\end{array}$ \\
\hline \multicolumn{9}{|l|}{ Sleeping time } \\
\hline Less than $7 \mathrm{~h}$ & 1 (ref.) & 1 (ref.) & 1 (ref.) & 1 (ref.) & 1 (ref.) & 1 (ref.) & 1 (ref.) & 1 (ref.) \\
\hline $7 \mathrm{~h}$ or more & $\begin{array}{l}0.92 \\
(0.39-2.17)\end{array}$ & $\begin{array}{l}0.78 \\
(0.31-1.98)\end{array}$ & $\begin{array}{l}0.73 \\
(0.32-1.67)\end{array}$ & $\begin{array}{l}0.73 \\
(0.31-1.70)\end{array}$ & $\begin{array}{l}0.84 \\
(0.41-1.73)\end{array}$ & $\begin{array}{l}0.82 \\
(0.39-1.73)\end{array}$ & $\begin{array}{l}1.01 \\
(0.46-2.23)\end{array}$ & $\begin{array}{l}1.15 \\
(0.51-2.59)\end{array}$ \\
\hline \multicolumn{9}{|l|}{ Sporting activity } \\
\hline No sports & 1 (ref.) & 1 (ref.) & 1 (ref.) & 1 (ref.) & 1 (ref.) & 1 (ref.) & 1 (ref.) & 1 (ref.) \\
\hline Sports & $\begin{array}{l}0.45^{*} \\
(0.23-0.87)\end{array}$ & $\begin{array}{l}0.16^{* *} \\
(0.06-0.46)\end{array}$ & $\begin{array}{l}0.98 \\
(0.49-1.99)\end{array}$ & $\begin{array}{l}1.27 \\
(0.53-.3 .01)\end{array}$ & $\begin{array}{l}0.76 \\
(0.42-1.36)\end{array}$ & $\begin{array}{l}0.90 \\
(0.44-1.84)\end{array}$ & $\begin{array}{l}0.62 \\
(0.32-1.20)\end{array}$ & $\begin{array}{l}0.50 \\
(0.22-1.14)\end{array}$ \\
\hline \multicolumn{9}{|l|}{ Having breakfast } \\
\hline No breakfast & 1 (ref.) & 1 (ref.) & 1 (ref.) & 1 (ref.) & 1 (ref.) & 1 (ref.) & 1 (ref.) & 1 (ref.) \\
\hline Breakfast & $\begin{array}{l}0.98 \\
(0.43-2.23)\end{array}$ & $\begin{array}{l}1.01 \\
(0.42-2.41)\end{array}$ & $\begin{array}{l}0.56 \\
(0.25-1.25)\end{array}$ & $\begin{array}{l}0.55 \\
(0.24-1.23)\end{array}$ & $\begin{array}{l}0.98 \\
(0.49-1.98)\end{array}$ & $\begin{array}{l}0.96 \\
(0.47-1.95)\end{array}$ & $\begin{array}{l}0.55 \\
(0.23-1.30)\end{array}$ & $\begin{array}{l}0.56 \\
(0.23-1.32)\end{array}$ \\
\hline \multicolumn{9}{|c|}{ Non-Adventist adolescents } \\
\hline \multicolumn{9}{|l|}{ Hours watching TV } \\
\hline More than two hours & 1 (ref.) & 1 (ref.) & 1 (ref.) & 1 (ref.) & 1 (ref.) & 1 (ref.) & 1 (ref.) & 1 (ref.) \\
\hline Two hours or less & $\begin{array}{l}0.84 \\
(0.34-2.05)\end{array}$ & $\begin{array}{l}1.20 \\
(0.46-3.15)\end{array}$ & $\begin{array}{l}1.22 \\
(0.43-3.43)\end{array}$ & $\begin{array}{l}1.27 \\
(0.43-3.73)\end{array}$ & $\begin{array}{l}0.58 \\
(0.25-1.31)\end{array}$ & $\begin{array}{l}0.60 \\
(0.25-1.42)\end{array}$ & $\begin{array}{l}1.12 \\
(0.45-2.81)\end{array}$ & $\begin{array}{l}1.07 \\
(0.41-2.80)\end{array}$ \\
\hline \multicolumn{9}{|l|}{ Sleeping time } \\
\hline Less than $7 \mathrm{~h}$ & 1 (ref.) & 1 (ref.) & 1 (ref.) & 1 (ref.) & 1 (ref.) & 1 (ref.) & 1 (ref.) & 1 (ref.) \\
\hline $7 \mathrm{~h}$ or more & $\begin{array}{l}1.32 \\
(0.66-2.65)\end{array}$ & $\begin{array}{l}1.35 \\
(0.66-2.77)\end{array}$ & $\begin{array}{l}0.93 \\
(0.40-2.18)\end{array}$ & $\begin{array}{l}0.88 \\
(0.37-2.09)\end{array}$ & $\begin{array}{l}1.87 \\
(0.95-3.69)\end{array}$ & $\begin{array}{l}1.87 \\
(0.94-3.72)\end{array}$ & $\begin{array}{l}1.01 \\
(0.49-2.06)\end{array}$ & $\begin{array}{l}1.05 \\
(0.51-2.18)\end{array}$ \\
\hline \multicolumn{9}{|l|}{ Sporting activity } \\
\hline No sporting activity & 1 (ref.) & 1 (ref.) & 1 (ref.) & 1 (ref.) & 1 (ref.) & 1 (ref.) & 1 (ref.) & 1 (ref.) \\
\hline Sporting activity & $\begin{array}{l}1.54 \\
(0.73-3.20)\end{array}$ & $\begin{array}{l}1.53 \\
(0.63-3.68)\end{array}$ & $\begin{array}{l}1.01 \\
(0.42-2.43)\end{array}$ & $\begin{array}{l}1.15 \\
(0.42-3.17)\end{array}$ & $\begin{array}{l}0.87 \\
(0.43-1.73)\end{array}$ & $\begin{array}{l}0.70 \\
(0.31-1.56)\end{array}$ & $\begin{array}{l}0.99 \\
(0.47-2.07)\end{array}$ & $\begin{array}{l}1.02 \\
(0.43-2.42)\end{array}$ \\
\hline \multicolumn{9}{|l|}{ Having breakfast } \\
\hline No breakfast & 1 (ref.) & 1 (ref.) & 1 (ref.) & 1 (ref.) & 1 (ref.) & 1 (ref.) & 1 (ref.) & 1 (ref.) \\
\hline Breakfast & $\begin{array}{l}0.80 \\
(0.39-1.65)\end{array}$ & $\begin{array}{l}0.89 \\
(0.42-1.88)\end{array}$ & $\begin{array}{l}1.00 \\
(0.41-2.42)\end{array}$ & $\begin{array}{l}1.02 \\
(0.41-2.50)\end{array}$ & $\begin{array}{l}0.81 \\
(0.40-1.62)\end{array}$ & $\begin{array}{l}0.77 \\
(0.38-1.57)\end{array}$ & $\begin{array}{l}1.43 \\
(0.69-2.95)\end{array}$ & $\begin{array}{l}1.42 \\
(0.68-2.96)\end{array}$ \\
\hline
\end{tabular}

Note: ${ }^{a}$ Model 1: Adjusted for the other life-style behaviors; ${ }^{\mathrm{b}}$ Model 2: Adjusted for the other life-style behaviors + age, gender, type of residence, place of birth; OR Odds Ratio, $95 \% \mathrm{Cl}=95 \%$ Confidence Interval

${ }^{*} p<0.05,{ }^{* *} p<0.01$

with food risk behavior in the group of Adventist students. Specifically, adolescents who watched TV for 2 $\mathrm{h}$ or less per day were less likely to have risky eating pattern than those who watched TV for more than 2 h. Both the model 1 and 2 showed significant results consistently ( $p=0.044$, respectively). However, we did not find any significant results of associations between life-style behaviors and health outcomes in the group of non-Adventist adolescents.

\section{Discussion}

This study describes the association between Adventist affiliation and lifestyle behaviors among Mexican adolescents living in northeastern Mexico and figure out lifestyle behaviors to affect health outcomes in Adolescent and non-Adolescent students. The results of this pilot study showed that Adventist students were more likely to have healthier life-style behaviors than non-Adventist students. In addition, sporting activity and hours watching TV were 
found to be significantly associated with obesity risk and risky eating patterns, respectively. Public health literature have identified the most suitable interventions for adolescent populations to adopt healthy behaviors from an early age, and effectively deal with the growing trend of obesity as a primary cause of chronic non-communicable diseases in adolescents [37-39].

Previous studies have showed that religious affiliation could have a protective and motivating effect for adolescents by promoting healthy behaviors to decrease the risk of lifestyle-related diseases [7, 40]. Specifically, a study found that indicators of religiosity and spirituality had positive effects on adolescent health attitudes and behaviors [41]. The other study highlighted the importance of analyzing lifestyle factors on underweight, overweight and obesity prevalence [42]. The findings of these studies support those presented in this study that religious affiliation could affect life-style behaviors among adolescents and several life-style behaviors could be associated with health outcomes.

The result that average hours of watching TV for nonAdventist adolescents was about $3.7 \mathrm{~h}$ is consistent with those provided by National Health and Nutrition Survey [43] and the Federal Institute of Telecommunications [44], which reported that children and adolescent Mexicans from 4 to 12 years old watch television for over 4-5 h per day on average. In addition, we found that Adventist students had better sleep habit, including enough sleeping time ( $7 \mathrm{~h}$ or more) and earlier sleep time (11 o'clock or before), than non-Adventist students. This finding is supported by a report from the Sleep Foundation that the teenagers aged 14 to 17 years old are recommended to sleep for 8 to $10 \mathrm{~h}$ per day [45].

Our findings showed that Adventist adolescents had lower level of obesity risk (overweight and obesity) than non-Adventist adolescents. This result coincides with those of the previous study that Adventist students demonstrated a lower prevalence of overweight and obesity than non-Adventist population in Australia and the United States [8, 46]. Given that, the prevalence of overweight and obesity is low among the students evaluated when compared with data from the Nuevo Leon region [47]; it is suggested to measure the body composition (lean mass and body fat) to have a more specific criterion of their nutritional status. Furthermore, it is common to motivate Adventists to have breakfast every day considering the lifestyle promotion actions in Adventist institutions. Although this study did not evaluate the type of foods included in breakfast, which can define compliance with the recommendations regarding energy (kcal) and nutrients, the results showed that Adventist students are more likely to have breakfast than non-Adventist students.

However, this study did not find any significant differences in risky eating pattern between Adventist and non-Adventist groups. These results were unexpected in light of the Adventist principle which diet plays an essential theological role $[17,48]$. In particular, among the 8515 Adventist schools worldwide [49], these institutions serve vegetarian meals to their students and promote an atmosphere in of balance between diet, exercise and schoolwork [47]. A future study to explore the relationship between diet principle of Adventists and eating risk patterns (diet-related health outcomes) is needed.

Concerning self-reported body image, there were no differences between Adventist and non-Adventist students. Examining body image perception is relevant due to possible positive or negative effects on overall health. Positive self-perception has been related to greater resilience and better academic performance among adolescents $[50,51]$, whereas a negative body image has been linked to depression and low self-esteem [52, 53].

This study has several limitations. First, the authors were not able to find corresponding themes in the peer-review literature studies performed in Mexico. As a result, they had no previous baseline for comparison among adolescents of Adventist religion in Mexico. In addition, participants live in the same region and locality, which may create a bias. Thus, the results of this study may not be generalized to other population with different characteristics. Future research is needed to include and utilize different regions of Mexico with more participants for comprehensive results. In addition, this study used a self-reported survey, which could make some biases. Lastly, we did not include specific information about life-style behaviors, such as food items for breakfast and times for sporting activity, due to data availability issue. Therefore, it is suggested to specify life-style behaviors to evaluate effects of particular behaviors on health outcomes in future research. However, this study highlights the importance of some lifestyle behaviors and their health impacts between Adventist and non-Adventist adolescents in Mexico. Those behaviors can be predictors of short-term health, as championed by fundamental Adventist principles. It is a pioneering study since it evaluates the uniqueness of Mexican Adventist adolescents, whose religious affiliation provides them the opportunity to be healthy from the earliest stages of life.

\section{Conclusions}

Religious affiliation could serve as a predictor of healthy behaviors among adolescents. This study showed that Adventist students are more likely to have a healthier lifestyle behavior than non-Adventist students. More research is needed to understand lifestyle factors of the Mexican Adventist adolescent population, such as vegetarian diets, daily water consumption, early night rest, outdoor activities, and avoiding alcohol and tobacco consumption. These elements could be identified as predictors of physical health for adolescents in the long term. Given that the prevalence of risky eating behaviors is increasing among adolescents, effective 
and longitudinal interventions are required to keep adolescents involved and interested in a nutrition and lifestyle program, and consequently reduce short-term risk. The findings of this study suggest expanding this kind of research and it might be needed to individually address each of the adolescents' life risky behaviors and evaluate their relationships in their family and community.

\section{Abbreviations}

BMl: Body Mass Index; CDC: Centers for Disease Control and Prevention; FIT: Federal Institute of Telecommunications; SDA: Seventh day Adventist Church

\section{Acknowledgements}

The authors extend their gratitude to the students who participated in this study, and the regional education authorities and secretary of public education (No. 5). We acknowledge the inspection of school zone No. 79, and each of the participating school directors for permitting continuous student participation in the educational interventions as part of the school activities overseen by the secretary of public education / Sector Salud / Quiero Vivir Sano-ASD, and the project of "A culture in health for the adolescent." The authors also thank the trained students who participated in the fieldwork by applying questionnaires and taking anthropometric measurements.

\section{Authors' contributions}

MEAE, FJUS, and GC contributed to the conception and design of the manuscript. MEAE and JPSA contributed to the collection and management of the data. FJUS performed the analysis and the interpretation of the data in the first version of the manuscript. JB re-conducted all of the statistical analysis of the first revision based on the reviewers' comments, interpreted the data, wrote the methods and results sections, and helped MEAE and GC to re-write the manuscript for submission \#2. All authors have read and approved the final manuscript.

\section{Funding}

This project was carried out with the support of educational material provided by the Ministry of Education and Health in Mexico, through the School and Adolescent Health Program, and by the didactic materials granted by the Adventist school institutions for the dissemination of the eight-health principles program. The funding entities had no role in the design of the study, collection, analysis, and interpretation of data, and writing the manuscript. The open access publishing fees for this article have been covered by the Texas A\&M University Open Access to Knowledge Fund (OAKFund), supported by the University Libraries and the Office of the Vice President for Research.

\section{Availability of data and materials}

The datasets used and analyzed in this study are available from the corresponding author (Dr. Genny Carrillo, gcarrillo@tamu.edu) on reasonable request.

\section{Ethics approval and consent to participate}

The Ethics Committee of the Directorate of Teaching and Health Research of Health Ministry in Nuevo Leon State approved the study. Prior to data collection, we obtained a verbal consent from all of the adolescent participants and a written consent form from their parents. This procedure was approved by the Ethics Committee.

\section{Consent for publication}

Not applicable.

\section{Competing interests}

The authors declare that they have no competing interests. Dr. Genny Carrillo is a member of the editorial board (Associate Editor) of this journal; however, she had no role in the editorial process of this manuscript.

\section{Author details}

'Montemorelos University, Sciences of Health Faculty, Nutrition School, School of Public Health, Libertad 1300 Pte., C.P. 67500 Montemorelos, Nuevo Leon, Mexico. ${ }^{2}$ Colegio de la Frontera Norte, Progreso 503, Seccion 1, Amp Tierra y Esperanza, C.P. 26020 Piedras Negras, Coahuila, Mexico. ${ }^{3}$ Department of Environmental and Occupational Health, School of Public Health, Texas A\&M University, 212 Adriance Lab Road, Suite 110, College Station, TX, USA.

Received: 5 February 2019 Accepted: 4 December 2019

Published online: 19 December 2019

\section{References}

1. World Health Organization. Adolescents Report: Health Risks and Solutions. February 5, 2018.

2. World Health Organization. Report of the commission to end child obesity. WHO document production services. Genève Switzerland. 2016.

3. World Health Organization. Action plan for the prevention of obesity in childhood and adolescence. Session of the WHO regional committee 2014.

4. World Health Organization. Health for the world's teenagers: a second chance in the second decade. WHO/FWC/MCA/14.05.2014.

5. World Health Organization. Global Strategy for the health of women, children and adolescents 2016-2030. Survive, prosper, transform-ODS-2015.

6. Velten APC, Cade NV, Silva GAE, Oliveira ERA. Profile of mortality from external causes among seventh-day Adventists and the general populations. Cien Saude Colet. 2017;22(7):2375-82.

7. Craig BA, Morton DP, Kent LM, Gane AB, Butler TL, Rankin PM, Price KR. Religious affiliation influences on the health status and behaviours of students attending Seventh-day-Adventist schools in Australia, J Relig Health. 2018. Jun;57(3):994-1009.

8. Craig BA, Morton DP, Kent LM, Butler TL, Rankin PM, Price KR. Adolescents attending Seventh-Day Adventist Schools in Australia: 2001-2012. J Sch Health. 2017. Aug;87(8):630-7.

9. Kent LM, Reirerson P, Morton DP. "Live more": study protocol for a community based lifestyle education program addressing noncommunicable diseases in low-literacy areas of the south pacific. BMC Public Health. 2015;15:1221.

10. García G, Ellison CG, Sunil TS, Hill TD. Religion and selected health behaviors among Latinos in Texas. J Relig Health. 2013;52(1):18-31.

11. Miller WR. Thoresen CE. Spirituality, religion, and health. An emerging research field. American Psychologist. January 2003. Vol 58. Núm 1. 24-35.

12. Saunders DM, Leak J, Carver ME, Smith SA. Application of a faith-based integration tool to assess mental and physical health interventions. J Public Health Association. 2017;7(1):26-38.

13. Craig BA, Morton DP, Morey PJ, Kent LM, Gane AB, Butler TL, Rankin PM, Price KR. The association between self-rated health and social environments, health behaviours and health outcomes: a structural equation analysis. BMC Public Health. 2018;18(1):440.

14. Chun Shing Kwok, Saadia Umar, Phyo K, Myint, Mamas A. Mamas, Yoon K. Loke. (2014). Vegetarian diet, seventh Day Adventists and risk of cardiovascular mortality: A systematic review and meta-analysis. Int J of Cardiology. Oct 20. 2014. Vol 176. Issue 3, pages 680-686.

15. Fraser GE, Orlich MJ, Jaceldo-Siegl K. Studies of chronic disease in seventh day Adventists. Int J Cardiol. 2015;184:573.

16. Tharrey M, Mariotti F, Mashchak A, Barbillon P, Delattre M, Fraser GE. Patterns of plants and animal protein intake are strongly associated with cardiovascular mortality: The Adventist Health Study-2 cohort. Int J Epidemiol. 2018. Apr 2.

17. Banta JM, Hodkin G, Yi Z, Fanica A, Sabate J. The global influence of the seventh-day Adventist church on diet. Religions. 2018;9:251.

18. Acosta ME, Gutiérrez A. Guel, V. Escobar K, Mata E. Report on nutritional status, eating habits, eating behaviors and health in adolescents from the Citrus Region in the state of Nuevo Leon, Mexico. (in Spanish). 2005-2015. Montemorelos University, Nutrition and Public Health School. 2016.

19. Wallace JM, Forman TA. Religion's role in promoting health and reducing risk among American youth. Healt Educ Behav. 1998;25(6):721-41.

20. Badura P, Sigmundova D, Sigmund E, Madarasova Geckova A, Van Dijk JP, Reijneveld SA. Participation in organized leisure-time activities and risk behaviors in Czech adolescents. Int J Public Health. 2017;62(3):387-96.

21. Morton KR, Lee JW, Haviland MG, Fraser GE. Religious engagement in a risky family model predicting health in older black and white seventh day Adventists. Psycholog Relig Spiritual. 2012;4(4):298-311. 
22. Pitel L, Madarasova Gechova A, Kolarcik P, Halama P, Reijneveld SA, Dijk V, JP. Gender differences in the relationship between religiosity and healthrelated behaviour among adolescents. J Epidem Community Health. 2012. Dec;66(12):1122-8.

23. Boyes $R$, O'Sullivan DE, Linden B, Mc Isaac M, Pickett W. Gender-specific associations between involvement in team sport culture and Canadian adolescent is substance-use behavior. SSM Popul Health. 2017;3:663-73.

24. Badura P, Madarasoya Geckova A, Sigmundova D, Sigmund E, Van Dijk JP, Reijneveld SA. Can organized leisure-time activities buffer the negative outcomes of unstructured activities for adolescent's health? Int J Public Health. 2018. Jun 2.

25. Park S, Chiu W, Won D. Effects of physical education, extracurricular sports activities, and leisure satisfaction on adolescent's aggressive behavior: a latent growth modeling approach. PLoS One. 2017;12(4):e0174674.

26. Han S, Lee J, Park KG. Impact of extracurricular activities participation on youth delinquent behavior: an instrumental variables approach. J Adolesc 2017:58:84-95

27. Chao LH, Tsai MC, Liang YL, Strong C, Lin CY. From childhood adversity to problem behaviors: role of psychological and structural social integration. Pediatr Int. 2018;60(1):23-9.

28. Rusell LT, Beckmeyer JJ, Su-Rusell C. Family-centered care and positive development outcomes for youth with special health care needs: variations across family structures. Nursing. 2018;24(1):29-59.

29. Khambati N, Mahedy L, Heron J, Emond A. Educational and emotional health outcomes in adolescence following maltreatment in early childhood: a population-based study of protective factors. Child Abuse Negl. 2018;81: 343-53.

30. Rushing SNC, Hildebrandt NL, Grimes CJ, Roswell AJ, Christensen BC, Lambert WE. Healthy \& Empowered Youth: A positive youth development program for native youth. Am J Prev Med. 2017 Mar;52(3SE):s263-7.

31. Centers for Disease Control and Prevention. Division of Nutrition, Physical Activity, and Obesity. National Center for Chronic Disease Prevention and Health Promotion,. About Children and Teen BMI. 2019 [cited 20198 February 20, 2019]; Available from: https://www.cdc.gov/healthyweight/ assessing/bmi/childrens_bmi/about_childrens_bmi.html

32. Romero F. 2009. Percentiles tables of weight, height and bmi. Program for windows. [online]. Available in: https://www.ac.uma.es/ felipe/bmi/.

33. Unikel C, Villatoro JA, Medina-Mora ME, Fleis C, Alcántar EN, Hernández SA. Risk eating behaviors in Mexican adolescents. Data on the student population of Mexico City. (in Spanish). RIC. 2000;52(2):140-147.34.

34. Altamirano MB, Vizmanos B, Unikel C. Continuous risk eating behavior in adolescents in Mexico. (in Spanish). Rev Panam Public Health. 2011:30(5):401-7.

35. Gardner RM, Stara K, Jackson N, Friedman BM. Development and validation of two new scales for assessment for body image. Percept Mot Skills. 1999;87:981-93.

36. Rueda-Jaimes GE, López C, PA FSM, Rangel Martínez-Villaba AM. Validity and reliability of two scales of silhouettes to assess body image in adolescents students. Rev Colomb Psiquiat. 2012;41(1):101-10.

37. Olivares DE, Chambi FR, Chañi EM, Craig WJ, Pacheco SO, Pacheco FJ. Risk factors for chronic diseases and multimorbidity in a primary care context of Central Argentina: a web-based interactive and cross-sectional study. Int J Environ Res Public Health. 2017;2, 14(3).

38. Gobierno de Mexico. Centro Nacional para la Salud de la Infancia y Adolescencia. Programa de Atencion a la Salud de la Infancia. 2019 [cited 2019 04/12/2019]; Available from: https://www.gob.mx/salud/censia/ acciones-y-programas/infancia

39. Gobierno de Mexico. Centro Nacional para la Salud de la infancia y Adolescencia. Norma Oficial Mexicana NOM-047-SSA2-2015 para la atención a la salud del grupo etario de 10 a 19 años de edad,. 2019 [cited 2019 February 20]; Available from: https://eproofing.springer.com/journals_v2/ mainpage.php?token=|UV38TtZE4CIRReW7hl1 ozUES7ZXZQQE0nehJjX2Y80

40. Mueller PS, Plevak DJ, Rummans TA. Religious Involvement, Spirituality, and Medicine: Implications for clinical practice. Mayo Clin Proc. 2001;76(12):1225-35.

41. Rew $L$, Wong J. A systematic review of associations among religiosity/ spirituality among adolescent health attitudes and behaviors. J Adolesc Health. 2006;38(4):433-42.

42. Pengpid S, Peltser K. The prevalence of underweight, overweight/obesity and their related lifestyle factors in Indonesia. AIMS Public Health. 20142015;4(6):533-649.

43. INSP. National Health and Nutrition Survey 2016. Final income report. October 21, 2016. Mexico Federal Government. National Institute of Public
Health. page 76. http://transparencia.insp.mx/2017/auditorias-insp/12701_ Resultados Encuesta ENSANUT_MC 2016.pdf.

44. Federal Telecommunications Institute-IFT. Studies on offer and consumption of programming for children in radio, television broadcast and restricted. April 2018. Direction and Unit of Media and audiovisual contents. Available online in: http://www.ift.org.mx/files/comunicacion-y-medios. estudiosninosfinalacc.pdf. pages 19-20

45. Hirshkowitz M, Whiton k, Albert SM, et al. National sleep foundation's sleep time duration recommendations: methodology and results summary. Sleep Health. 2015;1(1):40-3.

46. Pawlak R, Sovyanhadi N. Prevalence of overweight and obesity among seven-day Adventist African American and Caucasian college students. Ethn Dis. 2009;19(2):111-4.

47. Secretaria de Salud de Nuevo Leon. Estrategia Estatal para la prevención y el control del sobrepeso, la obesidad y la diabetes del Estado de Nuevo Leon, . 2014 [cited 2019 Febrero 20]; Available from: http://www.cenaprece. salud.gob.mx/programas/interior/adulto/descargas/pdf/ EstrategiaSODNuevoLeon.pdf

48. Díaz de León-Vázquez C, Rivera-Márquez JA, Bojorquez-Chapela I, UnikelSantoncini C. Variables associated with disordered eating behaviors among freshman students from Mexico City. (in Spanish). Public Health Mex. 2017; 59:258-65.

49. SDA, 2018. Seventh-day Adventist world church statistics. Available on line: https://www.adventist.org/en/information/statistics/article/go/-/seventh-dayadventist-world-church-statistics-2016-2017/.

50. Buckner JC, Mezzacappa E, Beardslee WR. Characteristics of resilient youths living in poverty: the role of self-regulatory processes. Dev Psychopathol. 2003;15(1):139-62.

51. Skrove M, Lydersen S, Indredavik MS. Resilience factors may moderate the associations between puberal timing, body mass and emotional symptoms in adolescence. Acta Pediatr. 2016;105(1):96-104.

52. Trujano P, Nava C, De García M, Limón G, Alatriste AL, Merino MT. Disorders of body image: a study with preadolescents and reflections from gender perspective (in Spanish). Anales de Psicología. 2010;26(2):279-87.

53. Cromley TR, Knatz S, Rockwell R, Neumark-Sztainer D, Story M, Boutelle k. Relationships between body satisfaction and psychological functioning and weight-related cognitions and behaviors in overweight adolescents. J Adolescent Health. 2012;50(6):651-3.

\section{Publisher's Note}

Springer Nature remains neutral with regard to jurisdictional claims in published maps and institutional affiliations.
Ready to submit your research? Choose BMC and benefit from:

- fast, convenient online submission

- thorough peer review by experienced researchers in your field

- rapid publication on acceptance

- support for research data, including large and complex data types

- gold Open Access which fosters wider collaboration and increased citations

- maximum visibility for your research: over $100 \mathrm{M}$ website views per year

At BMC, research is always in progress.

Learn more biomedcentral.com/submissions 